\title{
Placental Changes in Anemia, Gestational Diabetes and Pregnancy Induced Hypertension
}

\author{
Mithil Potuganti ${ }^{\circledR 1}$, B. R. Zambare ${ }^{\circledR 2}$ \\ ${ }^{1}$ Assistant Professor, Department of Anatomy, DVVPF's Medical College, Ahmednagar, Maharashtra, India, ${ }^{2}$ Professor, Department of Anatomy, Shivaji College of \\ Physiotherapy, Shivaji Nagar, Pune, Maharashtra, India.
}

\section{Abstract}

Background: To assess the changes occurring in the placenta due to anemia, pregnancy induced hypertension (PIH), Gestational Diabetes Mellitus (GDM) and whether these changes were reversible with treatment when they were diagnosed in early stages. Subjects and Methods: The study is conducted in the Department of Obstetrics and Gynecology, DVVPF's Medical College, Ahmednagar on 200 anemic patients, 180 PIH patients and 650 GDM patients. Placentae were collected, stored in a 10\% formalin solution. Morphological changes in respect to shape, weight, diameter, thickness, number of cotyledons and site of insertion of the cord are observed and documented. Results: In anemic patients who has undergone treatment, there were a smaller number of irregular (37/100) and round (63/100) round placentae were seen, whereas in the untreated anemic group, round (09/100) round and irregular (91/100) irregular placentae were seen. In PIH group with treatment, round (57/90) placentae and irregular (33/90) placentae were seen, whereas, in the untreated group, 13/100 round/oval placentae were observed and 77/100 irregular placentae were seen. Conclusion: Morphology of placenta is on error mode in untreated anemia, PIH and GDM. Diagnosis in the first trimester and on consequent treatment till the delivery is resulting in decreasing of irregular morphology of placenta and wellbeing of newborns.

Keywords: Placenta, Anemia, Pregnancy Induced Hypertension, Gestational Diabetes Mellitus.

Corresponding Author: Mithil Potuganti, Assistant Professor, Department of Anatomy, DVVPF's Medical College, Ahmednagar, Maharashtra, India.

E-mail:pmithil@gmail.com

Received: 30 June 2020

Revised: 16 August 2020

Accepted: 25 August 2020

Published: 24 December 2020

\section{Introduction}

The placenta is a mirror that reflects the intrauterine status of the fetus. promotes normal fetal development. It is an organ that connects the developing fetus to the uterine wall, thereby allowing nutrient uptake, waste elimination, and gas exchange via the mother's blood supply. Proper vascular development in the placenta is fundamental to ensuring a healthy fetus and successful pregnancy required for spontaneous induction of labor. ${ }^{[1]}$ Oxygen availability has proved as a critical factor in the development of the placenta and placental blood vessels too. ${ }^{[2]}$ It is known to have important functions, as an endocrine organ and in maternal-fetal exchange. ${ }^{[3,4]}$

Anemia in pregnancy is well recognized and often observed in developing countries. The severity of anemia among expectant mothers is judged by criteria suggested by the world health organization (WHO). Severe anemia is a perilous hematological disorder, due to which late abortions, prematurity, low birth weight and stillbirths are occurring. The global prevalence of anemia in pregnancy is $55.9 \%$ and in
India, the incidence has been noted as high as $40-80 \%{ }^{[5]}$

Hypertension (HTN) in pregnancy may be chronic hypertension (onset before pregnancy) or may be induced due to pregnancy, preeclampsia and eclampsia. These disorders form one of the deadly triads along with hemorrhage and infection resulting in a substantial number of maternal deaths and thereby fetal deaths. It affects $7-10 \%$ of pregnancies throughout the world. HTN in pregnancy is found to be associated with variable histomorphological changes in the placenta, which shows a clear reflection of poor foetal outcome. ${ }^{[6]}$

Gestational diabetes mellitus (GDM) is described as glucose intolerance of varying severity with the onset or first recognition during pregnancy and disappears with deliverycommon metabolic problem complicates approximately $2-4 \%$ of pregnancies and it is the major cause of macrosomia and perinatal mortality and usually associated by clinical hyperglycemia, hyperlipidemia, hyperinsulinemia and placental endothelial dysfunction. ${ }^{[7-9]}$ In India the prevalence of GDM is $4-11.6 \%$ and varies according to geographical areas and diagnostic 
methods employed. ${ }^{[10,11]}$

With a multifaceted trait, the placenta is exposed to the regulatory influence of hormones present in both fetal and maternal circulations and is affected by changes in any of these. As a fundamental organ with complexities of intrauterine life, the placenta grabs a pliant response and tries to remunerate to prevent any fetal complications. It remodels in weight, volume, structure, shape and functions tirelessly throughout gestation to maintain prenatal life. ${ }^{[12]}$

Considering the outcomes of these diseases on the development of the placenta and further that of foetus and also the changes that occur microscopically in the placenta, we decided to study this topic using different staining methods. Going through the literature, we observed earlier researchers had done the morphological and histological studies of placenta only. In our study, we aim to study the changes in the placenta with and without treatment.

\section{Subjects and Methods}

After getting Institutional Ethics Committee clearance, this cross-sectional study was carried out in the department of Obstetrics and Gynaecology, DVVPF's Medical college and hospital.

\section{The study participants were divided into seven groups as follows:}

- Controls $(n=325)$

- GDMNT $(n=325)$ : Gestational diabetes without treatment

- GDMT (n=325) : Gestational diabetes with treatment

- PIHNT ( $=90)$ : Pregnancy-induced hypertension without treatment

- PIHT $(n=90)$ : Pregnancy-induced hypertension with treatment

- $\operatorname{ANENT}(n=100)$ : Anemia without treatment

- $\operatorname{ANET}(n=100)$ : Anemia with treatment

\section{Inclusion Criteria}

Only the pregnant women of 18-40 years of attending the obstetrics and gynecology and willing to participate in the study by signing an informed consent form were included. Patients who deliver in normal and Caesarean sections were included.

\section{Exclusion Criteria}

Patients who are less than 18 years and above 40, Patients with blood-borne infections like HIV, Hepatitis, Patients with drug abuse, alcohol and smoking were excluded.

\section{Method of Collection}

Placenta specimens were collected from the obstetrics and gynecology department and stored in a $10 \%$ formalin solution and then morphometrical studies were conducted on it.

\section{Variables}

In placentae, the following parameters were measured:

Morphological changes in respect to

Shape, Weight, Diameter in the above disease conditions.

\section{Statistical Analysis}

Was carried out by using SPSS14. Data expressed as mean, standard deviation and percentages as applicable. Kolmogrov smrinov test was used to assess the normality. The betweengroup analysis was done by using an independent t-test. Null hypothesis was rejected at 0.05 .

\section{Results}

To study the role of treatment in placental and umbilical cord changes due to anemia, gestational diabetes and pregnancyinduced hypertension, three hundred and twenty-five controls, three hundred twenty-five pregnants with gestational diabetes with treatment, without treatment, ninety pregnancy-induced hypertensives with treatment and without treatment, one hundred pregnants with gestational diabetes on treatment and without treatment were studied.

Baseline details like age, height, weight, the information about parity and type of delivery in between the groups were given in [Table 1].

[Table 2] shows the shape of the placenta in study groups. The Control group has 298 round/oval-shaped and twentyseven irregular placentas. In the anemic group with treatment, there was less number of irregular $37 / 100$ and 63/100 round placentas were seen, whereas in the untreated anemic group contains 09/100 round/oval placentas and 91/100 irregular placentas were seen. In the pregnancy-induced hypertension group, those who are treated had 57/90 round placentas and $33 / 100$ irregular placentas were seen, whereas in the untreated pregnancy-induced hypertension group 13/100 round/oval and 77/100 irregular placentas were seen.

The weight of the placenta in study participants was depicted in [Table 3]. The untreated anemic group had the highest value when compared to control and all other patients.

[Table 4] shows the diameter of the placenta among various groups of the study. The lowest diameter was seen in the untreated pregnancy induced hypertension group. The thickness of the placenta in study groups was depicted in [Table 5, Figure 6]. The untreated anemic group had the lowest thickness. 


\begin{tabular}{|c|c|c|c|c|c|c|c|c|}
\hline \multirow[t]{3}{*}{ S.No } & \multirow[t]{3}{*}{ Parameter } & \multicolumn{7}{|l|}{ Group } \\
\hline & & GDMNT & GDMT & PIHNT & PIHT & ANENT & ANET & Controls \\
\hline & & $(n=325)$ & $(n=325)$ & $(n=90)$ & $(n=90)$ & $(n=100)$ & $(n=100)$ & $(n=325)$ \\
\hline 1 & Age & $\begin{array}{l}27.20 \\
(3.31)\end{array}$ & $\begin{array}{l}26.98 \\
(3.30)\end{array}$ & $\begin{array}{l}27.23 \\
(3.35)\end{array}$ & $\begin{array}{l}26.94 \\
(3.11)\end{array}$ & $\begin{array}{l}27.40 \\
(3.31)\end{array}$ & $\begin{array}{l}27.10 \\
(3.28)\end{array}$ & $26.94(3.34)$ \\
\hline 2 & Height & $\begin{array}{l}156.59 \\
(5.52)\end{array}$ & $\begin{array}{l}156.64 \\
(5.55)\end{array}$ & $\begin{array}{l}156.70 \\
(5.55)\end{array}$ & $\begin{array}{l}156.36 \\
(5.72)\end{array}$ & $\begin{array}{l}156.54 \\
(5.71)\end{array}$ & $\begin{array}{l}155.62 \\
(6.53)\end{array}$ & $\begin{array}{l}156.36 \\
(5.62)\end{array}$ \\
\hline 3 & Weight & $\begin{array}{l}62.53 \\
(10.53)\end{array}$ & $\begin{array}{l}64.30 \\
(11.51)\end{array}$ & $\begin{array}{l}65.67 \\
(12.91)\end{array}$ & $\begin{array}{l}66.07 \\
(14.20)\end{array}$ & $\begin{array}{l}65.89 \\
(12.55)\end{array}$ & $\begin{array}{l}66.65 \\
(11.80)\end{array}$ & $\begin{array}{l}63.75 \\
(11.03)\end{array}$ \\
\hline 4 & Parity P1 P2 & 88237 & 94231 & 3852 & 2961 & 3862 & 4258 & 78247 \\
\hline 5 & $\begin{array}{l}\text { Type of } \\
\text { delivery } \\
\text { Caesarean } \\
\text { Vaginal }\end{array}$ & 29530 & 27352 & 8307 & 7812 & 9307 & 8911 & 136189 \\
\hline
\end{tabular}

Data of age, height and weight was expressed as mean (SD), parity and type of delivery data is the actual number.

GDMNT: Gestational Diabetes without treatment; GDMT: Gestational Diabetes with treatment; PIHNT: Pregnancy-induced hypertension without treatment. PIHT: Pregnancy-induced hypertension with treatment. ANENT: Anemia without treatment.

\begin{tabular}{|c|c|c|c|c|c|c|c|c|}
\hline \multirow[t]{2}{*}{ S.No } & \multirow[t]{2}{*}{ Parame- } & \multicolumn{7}{|l|}{ Group } \\
\hline & & GDMNT & GDMT & PIHNT & PIHT & ANENT & ANET & Controls \\
\hline 1 & Round/oval & 33 & 125 & 13 & 57 & 09 & 63 & 398 \\
\hline 2 & Irregular & 292 & 200 & 77 & 33 & 91 & 37 & 27 \\
\hline
\end{tabular}

Data expressed as mean (SD)

GDMNT $=$ Gestational diabetes without treatment. GDMT = Gestational Diabetes with treatment. PIHNT= Pregnancy-induced hypertension without treatment. PIHT = Pregnancy-induced hypertension with treatment. ANENT: Anemia without treatment. ANET= Anemia with treatment.

Table 3: Weight of placenta in study participants

\begin{tabular}{|c|c|c|c|c|c|c|}
\hline \multicolumn{7}{|l|}{ Group } \\
\hline $\begin{array}{l}\text { GDMNT } \\
(n=325)\end{array}$ & $\begin{array}{r}\text { GDMT } \\
(\mathrm{n}=325)\end{array}$ & $\begin{array}{l}\text { PIHNT } \\
(n=90)\end{array}$ & PIHT $(n=90)$ & $\begin{array}{l}\text { ANENT } \\
(n=100)\end{array}$ & $\begin{array}{l}\text { ANET } \\
(n=100)\end{array}$ & $\begin{array}{l}\text { Controls } \\
(n=325)\end{array}$ \\
\hline
\end{tabular}

Data expressed as mean (SD)

$* * \mathrm{p}<0.001$

GDMNT $=$ Gestational diabetes without treatment. GDMT $=$ Gestational Diabetes with treatment. PIHNT= Pregnancy-induced hypertension without treatment. PIHT = Pregnancy-induced hypertension with treatment. ANENT: Anemia without treatment. ANET= Anemia with treatment.

Table 4: Diameter of the placenta in study participants

\begin{tabular}{lllllll}
\hline $\begin{array}{l}\text { Group } \\
\text { GDMNT } \\
(\mathbf{n = 3 2 5})\end{array}$ & $\begin{array}{l}\text { GDMT } \\
(\mathbf{n = 3 2 5})\end{array}$ & $\begin{array}{l}\text { PIHNT } \\
\mathbf{( n = 9 0 )}\end{array}$ & PIHT $(\mathbf{n = 9 0 )}$ & $\begin{array}{l}\text { ANENT } \\
(\mathbf{n = 1 0 0})\end{array}$ & $\begin{array}{l}\text { ANET } \\
(\mathbf{n}=\mathbf{1 0 0})\end{array}$ \\
$19.68(3.23)$ & $18.21(2.60)^{*}$ & $16.09(1.58)$ & $17.48(2.51)^{*}$ & $16.18(1.65)$ & $21.82(1.29) * *$ & $22.10(1.33)$ \\
\hline
\end{tabular}

Data expressed as mean (SD)

$* * \mathrm{p}<0.001, \mathrm{p}<0.05$

GDMNT $=$ Gestational diabetes without treatment. GDMT $=$ Gestational Diabetes with treatment. PIHNT= Pregnancy-induced hypertension without treatment. PIHT $=$ Pregnancy-induced hypertension with treatment. ANENT: Anemia without treatment. ANET= Anemia with treatment. 
Table 5: Shows the comparison between our study and various other studies.

\begin{tabular}{llll} 
Parameter & Author & Author's finding & Current study \\
Weight & Rohini. M et.,al & 410 gm in anemia & 488 gm in anemia \\
Weight & Udainia.A, Jain.M.L., & $370-435$ gm in PIH & 482 gm in PIH \\
Weight & El Sawy.N.A., Iqbal & 593.1 gm in GDM & 598 gm in GDM \\
\hline
\end{tabular}

\section{Discussion}

This study was carried out to understand the role of treatment in placental changes due to anemia, gestational diabetes and pregnancy-induced hypertension, three hundred and twentyfive controls, three hundred twenty-five pregnants with gestational diabetes with treatment, without treatment, ninety pregnancy-induced hypertensives with treatment and without treatment, one hundred pregnants with gestational diabetes on treatment and without treatment were studied.

Some remote areas of developing countries like India have still had no access to proper medical care. Hence, this study was conducted to compare the beneficial effects of medical management in maternal anemia, gestational diabetes and pregnancy-induced hypertension. ${ }^{[13]}$

Morphometric analysis hinges on many factors such as a number of analysed placentas, interactions between anemia and malnutrition of expectant mothers. Measurement of placental volume done through ultrasound between $11^{\text {th }}$ and $13^{\text {th }}$ gestational week didn't reveal any prominent alterations among anemic mothers. ${ }^{[14]}$ The baseline characteristics like age, height and weight of participants in between controls and the anemic group were same in our study.

The placentas used in our study weighted from $372.2 \mathrm{~g}$ to $469.52 \mathrm{~g}$. The lowest weight was seen in the untreated pregnancy induced hypertension group. Variations like these and fragmentarily opposite values are earlier identified as possible and familiar among anemic mothers and maternal anemia. Thus, it shows a nondependent risk factor for maldevelopment of the placenta. Older literature indicates hypertrophy is dependent on the duration time of hypoxia, but with the advancement of pregnancy, changes to growth restriction and formation of small, hypertrophic placenta. When analogised with our study, anemic mother's placentas total volume is the same as placentas from high altitude pregnancies that are considered as a preplacental hypoxic condition. ${ }^{[15,16]}$

In a hypoxic situation, placental blood vessels continue to develop with the branching model of angiogenesis till the end of pregnancy, which finally shows short terminal villi with numerous cross-sections of blood capillaries. ${ }^{[17-20]}$

Lack of iron, not any other reason, in early pregnancy, is a causative factor for anemia, which in turn is becoming a double-sized risk for pre-term delivery of low birth weight.
Contradicting data from $3^{\text {rd }}$ world countries where, among the well-nourished maternal population, lower iron status of expecting mothers is affiliated with higher birth weight and longer pregnancies. ${ }^{[21-28]}$

The usual term placenta is about $22 \mathrm{~cm}$ in diameter and 2.0 to $2.5 \mathrm{~cm}$ thick. However, the measurements can vary considerably, and placentas generally are not weighed in the delivery room. The maternal surface of the placenta should be dark maroon in color and should be divided into lobules or cotyledons. The structure should appear complete, with no missing cotyledons. The fetal surface of the placenta should be shiny, gray and translucent enough that the color of the underlying maroon villous tissue may be seen. ${ }^{\text {[29-33] }}$

The a placental thickness of $>40 \mathrm{~mm}$ at term is associated with gestational diabetes, intrauterine infections and hydrops foetalis. ${ }^{[34]}$ La Torre opined that at no stage of the pregnancy placental thickness exceeded $40 \mathrm{~mm}$ indirectly, thus indicating the cut-off value for the upper limit. ${ }^{[35]}$ Among the pregnant women with CMV infections, the placental thickness was increased in about $93.3 \%$ of the subjects. ${ }^{[36]}$

There can be several variations with cord insertion into the placenta: central insertion $(\sim 90 \%)$ is the normal situation, eccentric cord insertion: lateral insertion of the umbilical cord $>2 \mathrm{~cm}$ from the placental margin, the term sometimes used synonymously with marginal cord insertion, marginal cord insertion $(\sim 7 \%)$ : insertion of the umbilical cord $<2 \mathrm{~cm}$ from the placental margin, velamentous cord insertion $(\sim 1 \%)$ : insertion of the umbilical cord on the fetal, chorioamnionitis) membranes. [37]

The form of the human placenta is generally classified as a discoid placenta. Within this, the cotyledons are the approximately 15-25 separations of the deciduas basalis of the placenta, separated by placental septa. ${ }^{[38]}$ Each cotyledon consists of the main stem of a chorionic villus as well as its branches and sub-branches.

[Table 2] shows the shape of the placenta in study groups. The Control group has 298 round/oval-shaped and twentyseven irregular placentas. In the anemic group with treatment, there was less number of irregular $37 / 100$ and 63/100 round placentas were seen, whereas in the untreated anemic group contains 09/100 round/oval placentas and 91/100 irregular placentas were seen. In the pregnancy-induced hypertension group, those who are treated had 57/90 round placentas and $33 / 100$ irregular placentas were seen, whereas in the untreated 
pregnancy-induced hypertension group 13/100 round/oval and $77 / 100$ irregular placentas were seen.

The weight of the placenta in study participants was depicted in [Table 3]. The untreated anemic group had the highest value when compared to control and all other patients. ${ }^{[39]}$

[Table 4] shows the diameter of the placenta among the various group of the study. The lowest diameter was seen in the untreated pregnancy induced hypertension group. The thickness of the placenta in study groups as depicted in [Table 5]. The untreated anemic group had the lowest thickness. ${ }^{[40]}$

\section{Conclusion}

Morphology of placenta is on error mode in untreated anemia, PIH and GDM. Diagnosis in the first trimester and on consequent treatment till the delivery is resulting in decreasing of irregular morphology of placenta and wellbeing of newborns.

\section{References}

1. Amis D. Healthy Birth Practice: Let Labor Begin on Its Own. J Perinat Educ. 2014;23(4):178-187. Available from: https: //dx.doi.org/10.1891/1058-1243.23.4.178.

2. Huang A, Zhang R, Yang Z. Quantitative (stereological) study of placental structures in women with pregnancy irondeficiency anemia. Eur J Obstet Gynecol Reprod Biol . 2001;97(1):59-64. Available from: https://doi.org/10.1016/ s0301-2115(00)00480-2.

3. Jameson JL, Hollenberg AN. Regulation of chorionic gonadotropin gene expression. Endocr Rev. 1993;14(2):203224. Available from: https://doi.org/10.1210/edrv-14-2-203.

4. Srisuparp S, Strakova Z, Fazleabas AT. The Role of Chorionic Gonadotropin (CG) in Blastocyst Implantation. Arch Med Res. 2001;32(6):627-634. Available from: https://dx.doi.org/ 10.1016/s0188-4409(01)00330-7.

5. Rohini M, Yogesh AS, Goyal M, Kurrey P. Histological Changes in the Placentae from Severe Anaemic Mothers. Int J Med Health Sci. 2013;2(1):30-35.

6. Salmani D, Purushothaman S, Somashekara SC, Gnanagurudasan E, Sumangaladevi K, Harikishan R, et al. Study of structural changes in placenta in pregnancy-induced hypertension. J Nat Sci Biol Med. 2014;5(2):352-355. Available from: https://dx.doi.org/10.4103/0976-9668.136182.

7. Balaji V, Madhuri BS, Ashalatha S, Sheela S, S S, Seshiah V. A1C in Gestational Diabetes Mellitus in Asian Indian Women. Diabetes Care. 2007;30:1865-1867. Available from: https://dx.doi.org/10.2337/dc06-2329.

8. Alfadhli E. Gestational diabetes mellitus. Saudi Med J. 2015;36(4):399-406. Available from: https://dx.doi.org/10. 15537/smj.2015.4.10307.

9. Kalra P, Kachhwaha C, Singh H. Prevalence of gestational diabetes mellitus and its outcome in western Rajasthan. Indian J Endocrinol Metab. 2013;17(4):677-677. Available from: https://dx.doi.org/10.4103/2230-8210.113760.
10. Akgöl E, Abuşoğlu S, Gün FD, Ünlü A. Prevalence of gestational diabetes mellitus according to the different criterias. Turk J Obstet Gynecol. 2017;14(1):18-22. Available from: https://dx.doi.org/10.4274/tjod.38802.

11. Rajput R, Yadav Y, Nanda S, Rajput M. Prevalence of gestational diabetes mellitus \& associated risk factors at a tertiary care hospital in Haryana. Indian J Med Res. 2013;137(4):971-5916. Available from: http://www.ncbi.nlm. nih.gov/pmc/articles/pmc3724253/.

12. Teasdale F. Gestational changes in the functional structure of the human placenta in relation to fetal growth: A morphometric study. Am J Obstet Gynecol. 1980;137(5):560-568. Available from: https://dx.doi.org/10.1016/0002-9378(80)90696-1.

13. Laflamme EM. Maternal hemoglobin concentration and pregnancy outcome: a study of the effects of elevation in el alto, bolivia. Mcgill J Med. 2011;13(1):47-47.

14. Mayhew TM. Patterns of villous and intervillous space growth in human placentas from normal and abnormal pregnancies. Eur J Obstet Gynecol Reprod Biol. 1996;68(1-2):75-82. Available from: https://dx.doi.org/10.1016/0301-2115(96)02486-4.

15. Reshetnikova OS, Burton GJ, Milovanov AP. Effects of hypobaric hypoxia on the fetoplacental unit: the morphometric diffusing capacity of the villous membrane at high altitude. Am J Obstet Gynecol. 1994;171(6):1560-1565. Available from: https://doi.org/10.1016/0002-9378(94)90402-2.

16. Mayhew TM. Changes in Fetal Capillaries During Preplacental Hypoxia: Growth, Shape Remodelling and Villous Capillarization in Placentae from High-Altitude Pregnancies. Placenta. 2003;24(2-3):191-198. Available from: https://dx.doi.org/10. 1053/plac.2002.0895.

17. Hasegawa J, Nakamura M, Hamada S, Sekizawa A, Okai T. Is maternal anemia associated with small placental volume in the first trimester? Arch Gynecol Obstet. 2014;289(6):1207-1209. Available from: https://dx.doi.org/10.1007/s00404-014-31543.

18. Burton GJ, Reshetnikova OS, Milovanov AP, Teleshova OV. Stereological evaluation of vascular adaptations in human placental villi to differing forms of hypoxic stress. Placenta. 1996;17(1):49-55. Available from: https://dx.doi.org/10.1016/ s0143-4004(05)80643-5.

19. Allen LH. Biological mechanisms that might underlie iron's effects on fetal growth and preterm birth. J Nutr. 2001;131:581589. Available from: https://doi.org/10.1093/jn/131.2.581s.

20. Huppertz B. Placental origins of preeclampsia: challenging the current hypothesis. Hypertension. 2008;51(4):970-975. Available from: https://doi.org/10.1161/hypertensionaha.107. 107607.

21. Yildiz Y, Özgü E, Unlu SB, Salman B, Eyi EGY. The relationship between third trimester maternal hemoglobin and birth weight/length; results from the tertiary center in Turkey. J Matern-Fetal Neo M. 2014;27(7):729-732. Available from: https://dx.doi.org/10.3109/14767058.2013.837445.

22. Young MF, Pressman E, Foehr ML, McNanley T, Cooper $\mathrm{E}$, Guillet $\mathrm{R}$, et al. Impact of maternal and neonatal iron status on placental transferrin receptor expression in pregnant adolescents. Placenta. 2010;31(11):1010-1014. Available from: https://dx.doi.org/10.1016/j.placenta.2010.08.009. 
23. Ren A, Wang J, Ye RW, Li S, Liu JM, Li Z. Low first-trimester hemoglobin and low birth weight, preterm birth and small for gestational age newborns. Int J Gynecol. 2007;98(2):124-128. Available from: https://dx.doi.org/10.1016/j.ijgo.2007.05.011.

24. Kumar KJ, Murthy AN, Sujatha DS, Manjunath M, V. Maternal anemia in various trimesters and its effect on newborn weight and maturity: an observational study. Int J Prev Med. 2013;4(2):193-202.

25. Lelic M, Bogdanovic G, Ramic S, Brkicevic E. Influence of Maternal Anemia During Pregnancy on Placenta and Newborns. Medical Archives. 2014;68:184-184. Available from: https://dx.doi.org/10.5455/medarh.2014.68.184-187.

26. abdel Aziz Afifi RAR, Ali DK, Talkhan HM. Pregnancy Outcome and the Effect of Maternal Nutritional Status. J Egypt Soc Parasitol. 2013;43(1):125-132. Available from: https://dx.doi.org/10.12816/0006372.

27. Hubbard AC, Bandyopadhyay S, Wojczyk BS, Spitalnik SL, Hod EA, Prestia KA. Effect of dietary iron on fetal growth in pregnant mice. Comp Med. 2013;63(2):127-162.

28. Ervasti M, Sankilampi U, Heinonen S, Punnonen K. Early signs of maternal iron deficiency do not influence the iron status of the newborn, but are associated with higher infant birthweight. Acta Obstet Gynecol Scand. 2009;88(1):83-90. Available from: https://dx.doi.org/10.1080/00016340802595993.

29. Burton GJ, Jauniaux E. Development of the Human Placenta and Fetal Heart: Synergic or Independent? Front Physiol. 2018;9:373. Available from: https://dx.doi.org/10.3389/fphys. 2018.00373.

30. Cunningham FG, Leveno KJ, Bloom SL, Hauth JC, Gilstrap LC, Iii, et al. New York: McGraw- Hill; 2005.

31. Adair FL, Thelander H. A study of the weight and dimensions of the human placenta in its relation to the weight of the newborn infant. Am J Obstet Gynecol. 1925;10(2):172-205. Available from: https://dx.doi.org/10. 1016/s0002-9378(25)90719-3.

32. Naeye RL. Do placental weights have clinical significance? Human Pathol. 1987;18(4):387-391. Available from: https: //dx.doi.org/10.1016/s0046-8177(87)80170-3.

33. Joseph F, Yetter I. Examination of the Placenta. AFP. 1998;57(5):1045-1054.
34. Benrishke K, Kaufmann P. Anatomy and pathology of the umbilical cord and major foetal vessels. 2nded. New York: Springer-Verlag; 1998.

35. Grannum PA, Berkowitz RL, Hobbins JC. The ultrasonic changes in the maturing placenta. Am J Obstet and Gynecol. 1979;42:915-915. Available from: https://doi.org/10.1016/ 0002-9378(79)90312-0.

36. Tongsong T, Wanapirak C, Sirichotiyakul S. Placental thickness at mid-pregnancy as a predictor of $\mathrm{Hb}$ Bart's disease. Prenat Diagn. 1999;19:1027-1030. Available from: https://dx.doi.org/10.1002/(sici)1097-0223(199911) 19:11<1027::aid-pd691>3.0.co;2-c.

37. Weerakkody Y; Available from: https://radiopaedia.org/ articles/variation-in-cord-insertion.

38. Gordon Z, Elad D, Almog R, Hazan Y, Jaffa AJ, Eytan O. Anthropometry of fetal vasculature in the chorionic plate. J AnatomY. 2007;211(6):698-706. Available from: https://dx. doi.org/10.1111/j.1469-7580.2007.00819.x.

39. Udainia A, Jain ML. Morphological study of placenta in pregnancy induced hypertension with its clinical relevance. J Anat Soc India. 2001;50(1):24-27.

40. El-Sawy NA, Iqbal MS, Alkushi AG. Histomorphological Study of Placenta in Gestational Diabetes Mellitus. Int J Morphol. 2018;36(2):687-692. Available from: https://dx.doi. org/10.4067/s0717-95022018000200687.

Copyright: (C) the author(s), 2020. It is an open-access article distributed under the terms of the Creative Commons Attribution License (CC BY 4.0), which permits authors to retain ownership of the copyright for their content, and allow anyone to download, reuse, reprint, modify, distribute and/or copy the content as long as the original authors and source are cited.

How to cite this article: Potuganti M, Zambare BR. Placental Changes in Anemia, Gestational Diabetes and Pregnancy Induced Hypertension. Acad. Anat. Int. 2020;6(2):86-91.

DOI: dx.doi.org/10.21276/aanat.2020.6.2.19

Source of Support: Nil, Conflict of Interest: None declared. 